\title{
TELL SABI ABYAD, SYRIA: AN INTERPRETATION OF STABLE ISOTOPE VALUES OF FAUNAL BONE COLLAGEN
}

\author{
J van der Plicht ${ }^{1,2} \cdot \mathrm{P} \mathrm{M} \mathrm{M} \mathrm{G} \mathrm{Akkermans}^{2} \cdot \mathrm{H}_{\text {Buitenhuis }}^{3} \cdot \mathrm{A} \mathrm{Kaneda}^{2} \cdot \mathrm{O} \mathrm{Nieuwenhuyse}^{2} \cdot$ \\ A Russell ${ }^{2}$
}

ABSTRACT. At Tell Sabi Abyad, Syria, radiocarbon dating previously provided a robust chronology for the 7th-early 6 th millennium BC, the Late Neolithic. The continuous inhabitation spans the 8.2 ka climate event. This chronology has been used here in a study of stable isotope $\left({ }^{13} \mathrm{C}\right.$ and $\left.{ }^{15} \mathrm{~N}\right)$ data of animal bones. This is the first isotope study undertaken on material from this area. The results are used to explore diet and therefore animal management practices through the period $\sim 6800$ $5800 \mathrm{BC}$. A climatic signal could not be detected in the bone samples.

\section{INTRODUCTION}

The Neolithic in the Near East is an extremely important period in terms of animal domestication and animal husbandry. Many of the most economically important species, such as cattle, sheep, goats, and pigs, were first domesticated in this region, making it a key area of study (Renfrew 2006). The small but successful communities of the Late Neolithic in the 7th and 6th millennium BC have gained increasing interest over the years, particularly in light of the many material and social changes that occurred at this time (Akkermans and Schwartz 2003).

Tell Sabi Abyad, located in the Balikh region of northern Syria (see Figure 1), has been excavated intensively over the last decades. For a detailed description of the site, we refer to Akkermans et al. (2006). A striking observation is that around $\sim 6200 \mathrm{BC}$, many cultural changes are observed in architectural forms, settlement dynamics, pottery assemblage, other aspects of material culture, as well as animal exploitation. A large-scale ${ }^{14} \mathrm{C}$ dating program showed that the observed cultural change is contemporaneous with the 8.2 ka climate event (Alley et al. 1997; van der Plicht et al. 2011). The archaeological strata (18 levels, A12 to B3) provide now one of the best-dated continuous occupation sequences for the Late Neolithic in the region. The $8.2 \mathrm{ka}$ event corresponds to the transition from level Al to B8 (Akkermans et al. 2009).

Zoological studies and residue analyses point to several key changes in animal husbandry, notably the use of sheep and goats for milk and fiber production (Evershed et al. 2008). A "fiber revolution" is suggested by a substantial increase in the number of spindle whorls after $6200 \mathrm{BC}$; their size and weight suggest they were used for wool production. Finally, animal exploitation patterns show a substantial (albeit temporary) reduction of pig husbandry in favor of cattle husbandry. This change can possibly be linked to an aridification of the environment caused by the 8.2 ka event, as pigs are particularly maladapted to arid conditions (Balter 2010; Russell 2010). Indeed, climate modeling of the 8.2 ka event predicts dry conditions for the region (Wiersma and Renssen 2006).

In this paper, we present the first stable isotope data from Late Neolithic zooarchaeological material from the region. Stable carbon and nitrogen isotopes were analyzed from the bone collagen of ovicaprids, cattle, gazelle, and equid with the goal of illuminating the issues of the diet of ovicaprids, animal management practices, and perhaps paleoenvironmental conditions.

\footnotetext{
${ }^{1}$ Center for Isotope Research, Groningen University, Groningen, the Netherlands. Corresponding author. Email: J.van.der.Plicht@rug.nl.

2Faculty of Archaeology, Leiden University, Leiden, the Netherlands.

${ }^{3}$ Archaeological Research and Consultancy, Groningen, the Netherlands.
}

(C) 2012 by the Arizona Board of Regents on behalf of the University of Arizona Proceedings of the 6th International Radiocarbon and Archaeology Symposium, edited by E Boaretto and N R Rebollo Franco RADIOCARBON, Vol 54, Nr 3-4, 2012, p 281-289 


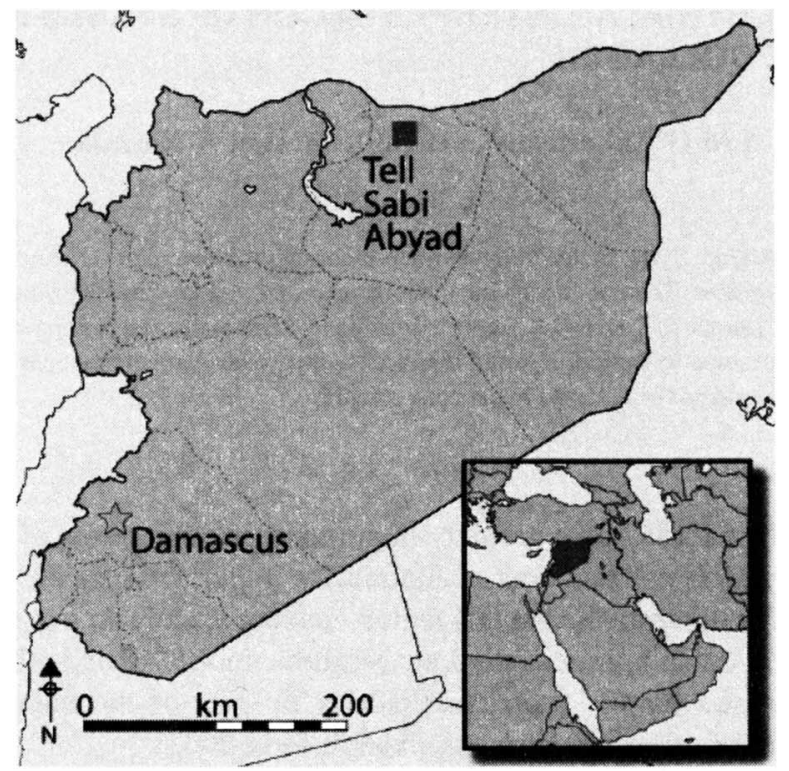

Figure 1 The location of Tell Sabi Abyad in northern Syria

\section{BONE ANALYSIS}

Over $170 \mathrm{~kg}$ of material were analyzed, comprising in total 48,802 bone fragments (Russell 2010). Ovicaprids (domestic sheep and goat) dominated the assemblage in all levels, and the main temporal changes were seen in the proportions of cattle, pigs, and both small and large wild game exploited at the site.

Faunal remains were one of the most abundant finds at the site and recent analyses of the fauna from $\sim 6800-5800 \mathrm{BC}$ have revealed an economy based around the husbandry of ovicaprids (making up $60-80 \%$ of the identified fauna) with an increasing input of domestic cattle through time (Russell 2010). Both the ovicaprids and cattle were domestic at the site, the ovicaprids throughout the assemblage and the cattle being domesticated in situ approximately 7000 BC. Both were exploited primarily for meat exploitation with perhaps some small-scale secondary production also taking place. The animal husbandry regime of the ovicaprids developed through time with the exploitation of these animals for secondary products becoming evident $\sim 6200 \mathrm{BC}$, showing a very stable, wellestablished form of ovicaprid herding at the site. Domestic pigs were also present at Tell Sabi Abyad but were almost entirely phased out by $\sim 6200 \mathrm{BC}$. Very low proportions of hunted fauna were recorded, but the assemblage included a wide range of bird and mammal species, the exploitation of which dwindled through time (Russell 2010).

\section{STABLE ISOTOPES}

The use of carbon and nitrogen isotopic abundances in bone collagen for paleodietary reconstruction has developed greatly over the past $20 \mathrm{yr}$. It is now a well-established technique used in the analysis of both diet and ecology in archaeological material (e.g. Kohn 1999; Hedges et al. 2004).

In this study, the stable isotope values of bone collagen, the protein component of bone, were analyzed in a sample of (mainly) ovicaprid bones from the site of Tell Sabi Abyad. A selection of other species was also included in this study, including bos, suids, equids, and gazelles, to act as compar- 
isons. Collagen extraction and isotopic analysis was undertaken and the stable isotope concentrations were measured by IRMS (isotope ratio mass spectrometry) at the Centre for Isotope Research in Groningen. The isotopic content of materials is expressed in delta $(\delta)$ values, which are defined as the deviation (expressed in \%o) of the rare to abundant isotope ratio from that of a reference material. For carbon, the reference material used was calcium carbonate in the shell of fossil belemnite from the PeeDee Formation (so-called PDB) in the USA. For nitrogen, the reference is ambient air. Bone collagen was prepared following an improved version of the Longin method (Longin 1971; Mook and Streurman 1983). The analytical error is 0.1 and $0.2 \%$ for $\delta^{13} \mathrm{C}$ and $\delta^{15} \mathrm{~N}$, respectively.

Once the samples had been processed, the following criteria were used to assess the preservation of the collagen. The $\mathrm{C}: \mathrm{N}$ atomic ratio was calculated $(\% \mathrm{C} / \% \mathrm{~N}$ multiplied by $14 / 12)$. The accepted range of atomic $\mathrm{C}: \mathrm{N}$ values for well-preserved prehistoric specimens is 2.90-3.54 (Ambrose 1990). Values outside this range are likely to have suffered diagenic alteration, causing changes to the organic composition, and should be eliminated from the data set as their ${ }^{13} \mathrm{C}$ and ${ }^{15} \mathrm{~N}$ values might have been shifted substantially and their use in dietary reconstruction might lead to erroneous conclusions (DeNiro 1985). Also, as a general rule, the carbon content should be around $30-40 \%$ and the nitrogen content around $10-15 \%$ for the results to be reliable, although sometimes lower values are acceptable (e.g. Rutgers et al. 2009).

\section{RESULTS}

The collagen from Tell Sabi Abyad bone material was generally poorly preserved, and many faunal samples failed or did not meet high enough collagen yields to be considered reliable. In total, 135 faunal bones were analyzed of which only $35(\sim 25 \%)$ met the quality requirements. For the different species, this is illustrated in Figure 2. The figure includes also human bone collagen samples for comparison. We have analyzed 92 human bones thus far; the success rate is comparable with that of the average fauna bones, i.e. around $1 / 3$. The human bone samples are part of a separate and still ongoing ${ }^{14} \mathrm{C}$ dating program, which is not further discussed here.

The low success rate is due to a low collagen content. This was probably the result of the aridity characteristic of the region, which can lead to collagen destruction shortly after burial (van Klinken 1999; Bocherens et al. 2000). Isotope studies on material from Anatolia have revealed the same problems with collagen preservation (Richards et al. 2003). This problem is also known in ${ }^{14} \mathrm{C}$ dating practice (Van Strydonck et al. 1998). Nevertheless, considering the age of the sample, i.e. 8000 yr old, the yield may actually be considered quite reasonable. The results of the accepted measurement results are shown in Table 1.

\section{DISCUSSION}

No isotopic differences were detected between the sheep and goat as separate species (Table 1 and Figure 3a). All values fit within a similar range and the bones assigned to either sheep, goats, or ovicaprids will further be considered together. The sampled population ranges in carbon from $\delta^{13} \mathrm{C}=-20.41$ to $-15.71 \%$ and in nitrogen from $\delta^{15} \mathrm{~N}=5.78$ to $11.44 \%$. This isotopic variability is assumed to equate to dietary variability and therefore infers there was a degree of dietary variability. These data illustrate a considerable isotopic variability in plant foraging by ovicaprids with a substantial proportion of $\mathrm{C}_{4}$ plants in the diet of some animals compared to a more exclusively $\mathrm{C}_{3}$ plant diet of others. The cut-off of $-18 \%{ }_{0} \delta^{13} \mathrm{C}$ is used to indicate the consumption of $\mathrm{C}_{4}$ plants (Pearson et al. 2007). The majority of the sample population had a diet dominated by $\mathrm{C}_{3}$ plants with approximately $22 \%$ also eating $\mathrm{C}_{4}$ plants. 


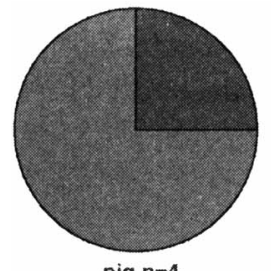

pig $n=4$
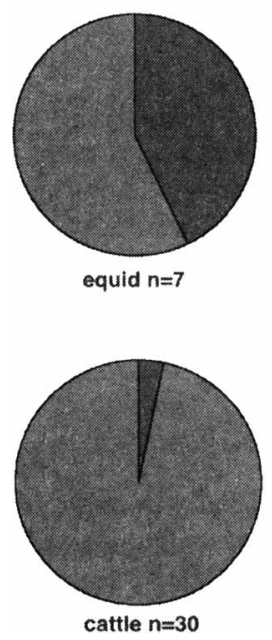
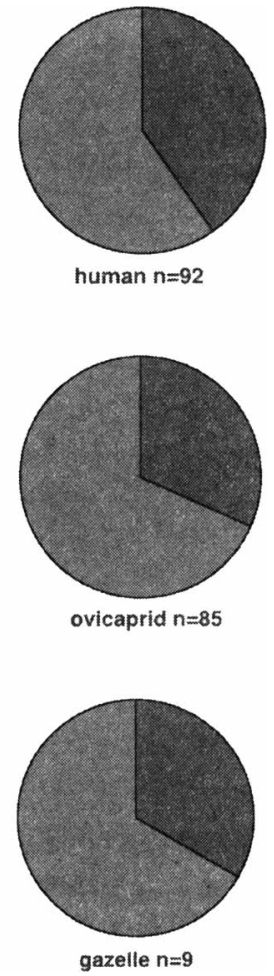

Figure 2 Collagen extraction success rate by species (including human bones, top right).

Looking at the average $\delta^{13} \mathrm{C}$ and $\delta^{15} \mathrm{~N}$ for the species bos, equid, gazelle, sus, and ovicaprid, one can see that there are some differences between the species (Table $2 \mathrm{a}$ and Figure $3 \mathrm{a}$ ). The wild herbivores of the steppe, equid and gazelle, show slightly more depleted $\delta^{13} \mathrm{C}$ values than for domestic cattle and ovicaprids, although they still fit within the isotopic range of these domestic animals. This suggests a diet of almost exclusively $\mathrm{C}_{3}$ plants for the equids and gazelles, while there was a proportion of $\mathrm{C}_{4}$ plants in the diet of some of the ovicaprids. Equids are also more depleted in $\delta^{15} \mathrm{~N}$, which is more difficult to explain. The more enriched $\delta^{15} \mathrm{~N}$ values in the domestic ovicaprids could also be a result of the animals being fed fodder from crops that were fertilized with animal dung and therefore enriched in nitrogen (Bogaard et al. 2007). The single successful cattle sample fits well within the range of the domestic ovicaprids. With only 1 successful $\delta^{13} \mathrm{C}$ and $\delta^{15} \mathrm{~N}$ value from cattle at Tell Sabi Abyad, it is not possible to go into any detail about the diet of these animals or any possible herding/feeding strategies. The 1 successful pig sample shows a relatively depleted $\delta^{13} \mathrm{C}$ value when compared to the domestic ovicaprids and a relatively enriched $\delta^{15} \mathrm{~N}$ value, although still within the range of ovicaprids. The lower $\delta^{13} \mathrm{C}$ value seen in this sample fits with samples from wild boar at archaeological sites in Iran (Bocherens et al. 2000), Turkmenistan (Bocherens et al. 2006), and Egypt (Thompson et al. 2005). This is probably due to their omnivorous diet and their preference for exclusively $C_{3}$ plants such as fruits, tubers, and other fleshy parts (Bocherens et al. 2000, 2006).

There is 1 data point that can be considered as an outlier: a sheep bone with $\delta^{13} \mathrm{C}=-15.71 \%$ and $\delta^{15} \mathrm{~N}=+11.44 \%$. $\mathrm{C}_{4}$ plant consumption could lead to such a heavy $\delta^{13} \mathrm{C}$ value. The high $\delta^{15} \mathrm{~N}$ value is harder to explain and requires further research. 
Table 1 Stable carbon and nitrogen isotope results for Tell Sabi Abyad faunal bone material.

\begin{tabular}{|c|c|c|c|c|c|c|c|}
\hline Species & Bone ID & $\delta^{13} \mathrm{C}$ & $\delta^{15} \mathrm{~N}$ & $\% \mathrm{C}$ & $\% \mathrm{~N}$ & Level & $\mathrm{C}: \mathrm{N}$ ratio \\
\hline Cattle & 15065 & -18.96 & 8.35 & 33.1 & 11.9 & A3 & 3.25 \\
\hline Equid & 18911 & -19.33 & 4.49 & 36.5 & 12.6 & Al & 3.38 \\
\hline Equid & 15122 & -19.77 & 4.20 & 38.9 & 14.3 & $\mathrm{~A} 2$ & 3.17 \\
\hline Equid & 15104 & -18.94 & 6.12 & 32.9 & 11.1 & A2 & 3.46 \\
\hline Gazelle & 15107 & -20.16 & 5.45 & 30.7 & 11.3 & $\mathrm{~A} 2$ & 3.17 \\
\hline Gazelle & 18260 & -18.29 & 7.28 & 39.4 & 15.3 & A9 & 3.00 \\
\hline Gazelle & 18173 & -19.07 & 7.96 & 35.9 & 12.3 & A9/A8 & 3.41 \\
\hline Pig & Pig 3 & -20.09 & 9.08 & 30.3 & 10.5 & - & 3.37 \\
\hline Sheep & 16243 & -18.78 & 7.63 & 31.6 & 11.0 & A4 & 3.35 \\
\hline Sheep & 3025 & -19.72 & 6.56 & 40.0 & 13.2 & A5 & 3.54 \\
\hline Sheep & 18657 & -18.82 & 7.83 & 40.4 & 13.9 & A5 & 3.39 \\
\hline Sheep & 18213 & -15.71 & 11.44 & 38.2 & 12.7 & A9 & 3.51 \\
\hline Sheep & 18269 & -20.01 & 5.78 & 33.7 & 11.5 & A9 & 3.42 \\
\hline Sheep & 15627 & -19.16 & 8.41 & 36.0 & 12.2 & B2 & 3.44 \\
\hline Sheep & 12715 & -18.56 & 9.56 & 39.7 & 14.9 & B6 & 3.11 \\
\hline Sheep & 15861 & -19.44 & 6.19 & 38.3 & 13.0 & A2 & 3.44 \\
\hline Sheep & 15756 & -18.80 & 8.09 & 41.7 & 14.5 & B3 & 3.36 \\
\hline Goat & 17518 & -18.31 & 9.37 & 40.8 & 14.7 & A10 & 3.24 \\
\hline Goat & 13095 & -18.89 & 8.08 & 39.0 & 14.2 & B6 & 3.20 \\
\hline Sheep/Goat & 16157 & -18.74 & 7.58 & 39.2 & 14.5 & A1 & 3.15 \\
\hline Sheep/Goat & 18944 & -17.12 & 7.86 & 36.4 & 14.4 & A1 & 2.95 \\
\hline Sheep/Goat & 14129 & -18.44 & 9.69 & 34.2 & 12.6 & Al & 3.17 \\
\hline Sheep/Goat & 16726 & -17.88 & 9.51 & 37.1 & 13.5 & Al & 3.21 \\
\hline Sheep/Goat & 17782 & -19.97 & 7.90 & 30.2 & 11.2 & A10 & 3.15 \\
\hline Sheep/Goat & 15285 & -20.41 & 5.99 & 40.4 & 14.0 & $\mathrm{~A} 2$ & 3.37 \\
\hline Sheep/Goat & 15127 & -18.58 & 8.63 & 41.0 & 14.4 & A2 & 3.32 \\
\hline Sheep/Goat & 15073 & -19.20 & 8.02 & 36.4 & 14.1 & A4 & 3.01 \\
\hline Sheep/Goat & 16382 & -19.57 & 6.15 & 36.7 & 13.1 & A4 & 3.27 \\
\hline Sheep/Goat & 18097 & -18.93 & 8.47 & 40.6 & 13.6 & A9 & 3.48 \\
\hline Sheep/Goat & 18137 & -17.59 & 8.66 & 39.6 & 15.1 & A9 & 3.06 \\
\hline Sheep/Goat & 18268 & -17.77 & 7.24 & 34.4 & 12.1 & A9 & 3.32 \\
\hline Sheep/Goat & 12816 & -19.34 & 7.39 & 34.1 & 11.5 & B4 & 3.46 \\
\hline Sheep/Goat & 13580 & -18.32 & 7.45 & 36.8 & 12.2 & B5 & 3.52 \\
\hline Sheep/Goat & 12937 & -18.03 & 7.65 & 41.2 & 15.5 & B6 & 3.10 \\
\hline Sheep/Goat & 13971 & -18.72 & 7.66 & 37.9 & 13.3 & B7 & 3.32 \\
\hline
\end{tabular}

The ovicaprid isotope data have also been analyzed by phase, to detect possible temporal differences in diet. Unfortunately, due to the small sample sizes by level, the data could only be grouped into 3 broad, arbitrary phases: A10-A3 (levels running up to the end of the A sequence); A2-A1 (the levels immediately before the end of the A sequence); and the B levels (Table $2 b$ and Figure $3 b$ ).

The levels A10-A3 are dated to 6865-6375 BC; A2-A1 to 6385-6225 BC; and B3-B8 to 61805995 BC (van der Plicht et al. 2011).

The sample population in phase $\mathrm{A} 10-\mathrm{A} 3$ ranges in $\delta^{13} \mathrm{C}$ from $-20.01 \%$ to $-15.71 \%$ and in $\delta^{15} \mathrm{~N}$ from $5.78 \%$ to $11.44 \%$. The range of the sample population in phase $\mathrm{A} 2-\mathrm{A} 1$ is smaller, with $\delta^{13} \mathrm{C}$ from $-20.41 \%$ to $-17.12 \%$ and $\delta^{15} \mathrm{~N}$ from 5.99 to 9.69 . There is a further narrowing of the isotopic, and therefore dietary, variability in the B levels, with $\delta^{13} \mathrm{C}$ from $-19.34 \%$ to $-18.03 \%$ and $\delta^{15} \mathrm{~N}$ from $7.39 \%$ to $9.56 \%$. This narrowing of variability is clear in both the $\delta^{13} \mathrm{C}$ values and the $\delta^{15} \mathrm{~N}$ 

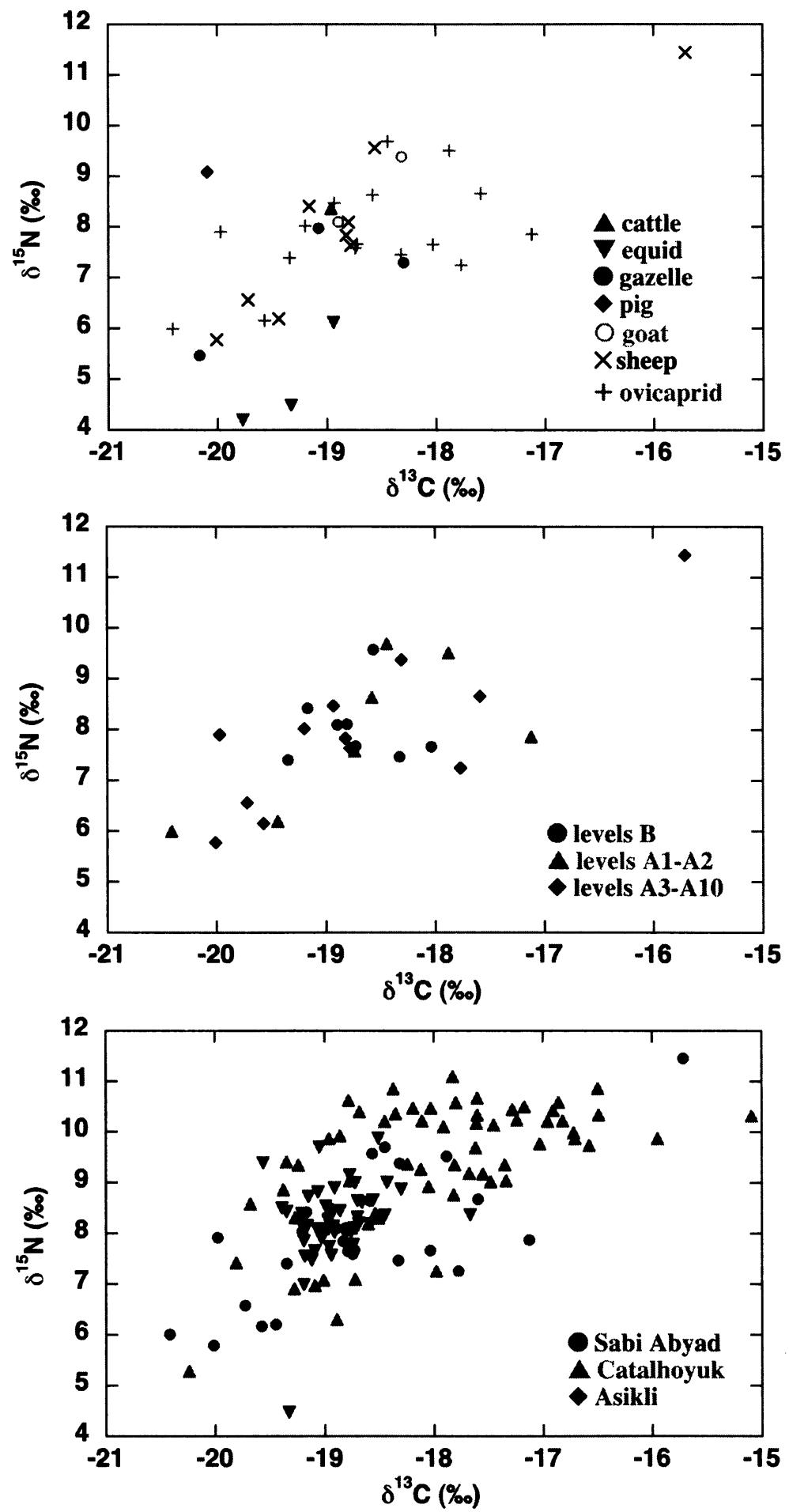

Figure 3 a) Ovicaprids, cattle, equid, gazelle, and pig stable carbon $\left(\delta^{13} \mathrm{C}\right)$ and nitrogen $\left(\delta^{15} \mathrm{~N}\right)$ values of bone collagen from Tell Sabi Abyad; b) Ovicaprid stable carbon $\left(\delta^{13} \mathrm{C}\right)$ and nitrogen $\left(\delta^{15} \mathrm{~N}\right)$ values of bone collagen from Tell Sabi Abyad by phase; c) Ovicaprid isotope results of Çatalhöyük, Asikli Höyük, and Tell Sabi Abyad. 
values by phase. With such small data sets for each phase, any interpretations of this apparent narrowing of diet must be undertaken with caution. The narrowing in the range of $\delta^{13} \mathrm{C}$ and $\delta^{15} \mathrm{~N}$ values after the $\mathrm{A}$ sequence suggests a reduction in the variability in the diet at this time. There is apparently less contribution of $\mathrm{C}_{4}$ plant species to the diet as no samples were over $-18 \%$. If the reduction in variability is real, this perhaps reflects the foddering of animals on $\mathrm{C}_{3}$ crop species. However, because of the relatively small sample size, this cannot be firmly established.

Table 2a Isotope variation by species.

\begin{tabular}{lrllll|llll}
\hline & \multicolumn{5}{c}{$\delta^{13} \mathrm{C}$} & \multicolumn{4}{c}{$\delta^{15} \mathrm{~N}$} \\
\cline { 2 - 10 } Levels & \multicolumn{1}{rl}{$n$} & Mean & SD & Min & Max & Mean & SD & Min & Max \\
\hline Sheep & 9 & -18.78 & 1.25 & -20.01 & -15.71 & 7.94 & 1.76 & 5.78 & 11.44 \\
Goat & 2 & -18.60 & 0.41 & -18.89 & -18.31 & 8.72 & 0.91 & 8.08 & 9.37 \\
Ovicaprid & 16 & -18.66 & 0.89 & -20.41 & -17.12 & 7.86 & 1.00 & 5.99 & 9.69 \\
Cattle & 1 & -18.96 & - & - & - & 8.35 & - & - & - \\
Gazelle & 3 & -19.17 & 0.94 & -20.16 & -18.29 & 6.89 & 1.30 & 5.45 & 7.96 \\
Equid & 3 & -19.35 & 0.42 & -19.77 & -18.94 & 4.94 & 1.04 & 4.20 & 6.12 \\
Pig & 1 & -20.09 & - & - & - & 9.08 & - & - & - \\
\hline
\end{tabular}

Table $2 \mathrm{~b}$ Isotope variation in ovicaprids by phase.

\begin{tabular}{lrllll|lllr}
\hline & & \multicolumn{4}{c|}{$\delta^{13} \mathrm{C}$} & \multicolumn{4}{c}{$\delta^{15} \mathrm{~N}$} \\
\cline { 2 - 10 } Levels & $n$ & Mean & SD & Min & Max & Mean & SD & Min & Max \\
\hline B & 8 & -18.73 & 0.43 & -19.34 & -18.03 & 8.03 & 0.71 & 7.39 & 9.56 \\
A2-A1 & 7 & -18.66 & 1.06 & -20.41 & -17.12 & 7.92 & 1.47 & 5.99 & 9.69 \\
A10-A3 & 12 & -18.70 & 1.23 & -20.01 & -15.71 & 7.92 & 1.52 & 5.78 & 11.44 \\
\hline
\end{tabular}

Table $2 \mathrm{c}$ Isotope variation in ovicaprids by site.

\begin{tabular}{llllll|llll}
\hline & & \multicolumn{4}{c|}{$\delta^{13} \mathrm{C}$} & \multicolumn{4}{c}{$\delta^{15} \mathrm{~N}$} \\
\cline { 2 - 10 } Levels & $n$ & Mean & SD & Min & Max & Mean & SD & Min & Max \\
\hline Catalhöyük & 60 & -17.98 & 1.01 & -20.24 & -15.09 & 9.39 & 1.27 & 5.28 & 11.09 \\
Asikli Höyük & 68 & -18.78 & 0.80 & -19.98 & -15.32 & 8.50 & 1.01 & 4.48 & 11.50 \\
Tell Sabi Abyad & 27 & -18.70 & 0.97 & -20.41 & -15.71 & 7.95 & 1.27 & 5.78 & 11.44 \\
\hline
\end{tabular}

We compared our data from Tell Sabi Abyad with those of Pearson et al. (2007) from the sites of Çatalhöyük and Asikli Höyük in Turkey; see Table 2c and Figure 3c. The sampled population from Çatalhöyük ranges in $\delta^{13} \mathrm{C}$ from $-20.24 \%$ o to $-15.09 \%$ and in $\delta^{15} \mathrm{~N}$ from $5.28 \%$ to $11.09 \%$. These data are very similar to those from Tell Sabi Abyad, suggesting that the range of plants eaten was very similar. This was not entirely the case when Tell Sabi Abyad was compared to Asikli Höyük, which had individuals ranging in $\delta^{13} \mathrm{C}$ from $-19.56 \%$ to $-17.67 \%$ and in $\delta^{15} \mathrm{~N}$ from $4.48 \%$ to 9.89\%. These data indicate that the animals from this site had far less dietary variation and very little contribution from $\mathrm{C}_{4}$ plants to the diet. This suggests that the ovicaprids from Tell Sabi Abyad had a diet more similar to those herded at Çatalhöyük than Asikli Höyük. This was to be expected as the ovicaprids from Asikli Höyük are only protodomestic and perhaps only loosely herded (Buitenhuis 1997), while the ovicaprids from Çatalhöyük are fully domestic (Russell and Martin 2005) as they are at Tell Sabi Abyad. At Çatalhöyük, there is a move from a diet essentially uniform in both $\delta^{13} \mathrm{C}$ and $\delta^{15} \mathrm{~N}$ values to a pattern of individually variable diet around $7300 \mathrm{BC}$ onwards. It is hypothesized by Pearson et al. (2007) that the increase in diet range reflects an increase in the significance of pastoralism with herders moving separate flocks over more extensive territories around 
the village where they came into contact with multiple isotopically distinctive plant biomasses. If this is the case, then the opposite is true at Tell Sabi Abyad; the decrease in diet range could reflect a decrease in the significance of pastoralism after $6200 \mathrm{BC}$. With our relatively small isotope data set from Tell Sabi Abyad, it is difficult to make such an interpretation.

\section{CONCLUSION}

In this paper, we investigated patterns of ovicaprid herding at a local scale through the analysis of stable carbon and nitrogen isotopes. A large sample of animal bones was selected, but unfortunately the collagen preservation of these $\sim 8000$-yr-old bones was not as good as was hoped. The success rate for obtaining good quality collagen was only about $25 \%$. The better preserved samples gave direct insight in to the diet of these Late Neolithic animals. Stable isotope analysis of some of the fauna at Tell Sabi Abyad has given us an insight into the individual diets of ovicaprids in the Late Neolithic (6750-5995 BC) of northern Syria, with some addition data from other species. The results of this study do provide enough information about the diet of the ovicaprids so as to allow tentative interpretations about herding practices in this area and period. Although it is not clear as to whether the flocks of sheep and goat were herded over large distances in a form of pastoral nomadism in the period of 6750-5995 BC, it is clear that some form of (perhaps fairly localized) pastoralism was taking place and that a wide range of distinct plant biomasses were in general grazed on by the flocks of sheep and goat at Tell Sabi Abyad.

The changes in the $\delta^{13} \mathrm{C}$ and $\delta^{15} \mathrm{~N}$ values of ovicaprids from Tell Sabi Abyad do not point directly and uniquely to climate change as a cause. Pearson et al. (2007) argue that climate variation would result in the unidirectional variation in carbon and/or nitrogen isotopic variation, with values either becoming more negative or positive over time. The small sample of isotopic data from Tell Sabi Abyad does not lend itself to such interpretations, and it is not possible to support or rule out climate variation within the sequence. If the effects of the climate change were more subtle and nuanced rather than catastrophic, then perhaps the apparent increase in the foddering of the animals seen from around level A1 (6225 BC) onwards was an animal management strategy undertaken to cope with a decrease in quality grazing pastures available locally due to an increase in aridity.

\section{ACKNOWLEDGMENT}

This work is funded by the Netherlands Organisation for Scientific Research (NWO), dossier 36062-040.

\section{REFERENCES}

Akkermans PMMG, Schwartz GM. 2003. The Archaeology of Syria: From Complex Hunter-Gatherers to Early Urban Societies (ca. 16000-300 BC). Cambridge: Cambridge University Press. $486 \mathrm{p}$.

Akkermans PMMG Cappers R, Cavallo C, Nieuwenhuyse $O$, Nilhamn $B$, Otte IN. 2006. Investigating the Early Pottery Neolithic of northern Syria: new evidence from Tell Sabi Abyad. American Journal of Archaeology 110(1):123-56.

Akkermans PMMG, van der Plicht J, Nieuwenhuyse O, Russell A, Kaneda A. 2009. Cultural transformation and the $8.2 \mathrm{ka}$ event in Upper Mesopotamia. In: PreModern Climate Change: Causes and Responses. Conference, Copenhagen (proceedings forthcoming). Alley RB, Mayewski PA, Sowers T, Stuiver M, Taylor
KC, Clark PU. 1997. Holocene climatic instability: a prominent, widespread event 8200 yr ago. Geology 25(6):483-6.

Ambrose SH. 1990. Preparation and characterization of bone and tooth collagen for isotopic analysis. Journal of Archaeological Science 17(4):431-51.

Balter M. 2010. In a cold snap, farmers turned to milk. Science 329(5998): 1465.

Bocherens H, Mashkour M, Billiou D. 2000. Palaeoenvironmental and archaeological implications of isotopic analyses $\left({ }^{13} \mathrm{C},{ }^{15} \mathrm{~N}\right)$ from Neolithic to present in Qazvin Plain (Iran). Environmental Archaeology 5:1-19.

Bocherens H, Mashkour M, Drucker DG, Moussa I, Billiou D. 2006. Stable isotope evidence for palaeodiets in southern Turkmenistan during Historical period and 
Iron Age. Journal of Archaeological Science 33(2): 253-64.

Bogaard A, Heaton THE, Poulton P, Merbach I. 2007. The impact of manuring on nitrogen isotope ratios in cereals: archaeological implications for reconstruction of diet and crop management practices. Journal of Archaeological Science 34(3):335-43.

Buitenhuis H. 1997. Aşikli Höyük: a "protodomestication" site. Anthropozoologica 25-26:655-62.

DeNiro MJ. 1985. Postmortem preservation and alteration of in vivo bone collagen isotope ratios in relation to palaeodietary reconstruction. Nature 317(6040): 806-9.

Evershed RP, Payne S, Sherratt AG, Copley MS, Coolidge J, Urem-Kotsu D, Kotsakis K, Ozdogan M, Özdoğan AE, Nieuwenhuyse O, Akkermans PMMG, Bailey D, Andeescu R-R, Campbell S, Farid S, Hodder I, Yalman N, Özbaşaran M, Erhan Biçakci E, Garfinkel Y, Levy T, Burton MM. 2008. Earliest date for milk use in the Near East and southeastern Europe linked to cattle herding. Nature 455(7212):528-31.

Hedges REM, Stevens RE, Richards MP. 2004. Bone as a stable isotope archive for local climatic information. Quaternary Science Reviews 23(7-8):959-65.

Kohn MJ. 1999. You are what you eat. Science 283(5400):335-6.

Longin R. 1971. New method of collagen extraction for radiocarbon dating. Nature 230(5291):241-2.

Mook WG, Streurman HJ. 1983. Physical and chemical aspects of radiocarbon dating. In: First Symposium on ${ }^{14} \mathrm{C}$ and Archaeology, Groningen. PACT 8:31-55.

Pearson JA, Buitenhuis H, Hedges REM, Martin L, Russell N, Twiss KC. 2007. New light on early caprine herding strategies from isotope analysis: a case study from Neolithic Anatolia. Journal of Archaeological Science 34(12):2170-9.

Renfrew C. 2006. Inception of agriculture and rearing in the Middle East. Comptes Rendus Palevol 5(1-2): 395-404.
Richards MP, Pearson JA, Molleson TI, Russell N, Martin L. 2003. Stable isotope evidence of diet at Neolithic Çatalhöyük, Turkey. Journal of Archaeological Science 30(1):67-76.

Russell A. 2010. Retracing the steppes: a zooarchaeological analysis of changing subsistence patterns in the Late Neolithic at Tell Sabi Abyad, northern Syria, 6900 to $5900 \mathrm{BC}$ [PhD thesis]. Leiden University.

Russell N, Martin L. 2005. Çatalhöyük mammal remains. In: Hodder I, editor. Inhabiting Çatalhöyük: Reports from the 1995-1999 Seasons. Cambridge: Cambridge University Press. p 32-98.

Rutgers LV, Van Strydonck M, Boudin M, van der Linde C. 2009. Stable isotope data from the early Christian catacombs of ancient Rome: new insights into the dietary habits of Rome's early Christians. Journal of Archaeological Science 36(5):1127-34.

Thompson AH, Richards MP, Shortland A, Zakrzewski SR. 2005. Isotopic palaeodiet studies of Ancient Egyptian fauna and humans. Journal of Archaeological Science 32(3):451-63.

van der Plicht J, Akkermans PMMG, Nieuwenhuyse O, Kaneda A, Russell A. 2011. Tell Sabi Abyad, Syria: radiocarbon chronology, cultural change and the 8.2 ka event. Radiocarbon 53(2):229-43.

van Klinken GJ. 1999. Bone collagen quality indicators for palaeodietary and radiocarbon measurements. Journal of Archaeological Science 26(6):687-95.

Van Strydonck M, Nelson DE, Crombé P, Bronk Ramsey C, Scott EM, van der Plicht J, Hedges REM. 1999. What's in a ${ }^{14} \mathrm{C}$ date. In: Evin J, Oberlin C, Daugas JP, Salles JF, editors. Radiocarbon and Archaeology: Proceedings of the 3rd International Symposium. Lyon, 1998. p 433-40.

Wiersma AP, Renssen H. 2006. Model-data comparison for the $8.2 \mathrm{ka}$ BP event: confirmation of a forcing mechanism by catastrophic drainage of Laurentide lakes. Quaternary Science Reviews 25(1-2):63-88. 